\title{
Labour Force Participation Rate in Agricultural and Non- Agricultural Activities in Sikkim with Special Emphasis on Women's Work Participation: Variation Across Districts
}

\author{
Kesang Wangmo Bhutia \\ Ph.D Scholar, Department of Economics, Raiganj University, West Bengal, India \\ Corresponding author: kesang1319@gmail.com
}

Received: 09 Apr., $2021 \quad$ Revised: 18 May, 2021

Accepted: 13 Jun., 2021

\begin{abstract}
The present study analyses the labour force participation rate in agricultural and non-agricultural activities in Sikkim with special emphasis on women's work participation and its variations across the districts. The study was based on secondary data that was collected for the agricultural workers, non-agricultural workers and total workers from the Census of India, 2011. The total agricultural workers comprised of the cultivators and the agricultural labourers; the total non-agricultural workers included workers in the household industry and other workers. Total workers consisted of the main workers and the marginal workers. The results were analyzed using descriptive statistics such as percentages and tabular representation. Both in the agricultural and the non-agricultural activities, men dominated women whose participation was found to be between, 50 to 72 per cent. However, while comparing the involvement of the men and the women as main and marginal workers, it was observed that 70 per cent of the men were involved as main workers and 56 per cent of the women were actively involved as marginal workers. Inter-district variations in all the categories of the work mentioned above were found in the state. Ultimately, it was realized that 50 per cent of the population of the state were working population and 50 per cent were dependent or non-working population. Such a result is a great concern to all the stakeholders of the state especially the policy makers. More employment opportunity is to be augmented in the state to involve more people in work to enhance the state's economy.
\end{abstract}

Keywords: Labour force Participation Rate, Women's Work Participation, Agricultural and NonAgricultural Sector, Variation Across the Districts, Gender

Participation of women in both agricultural and non-agricultural activities is essential for earning family income in ways beyond their traditional roles of crop production and animal husbandry. Their involvement 
in economic activities would motivate the entire communities in establishing a self-reliant society. The active participation of women has a crucial and positive impact on social and economic activities and would improve their living standards. The socio-economic development of any country depends on the proper participation of people from all walks of life. Women are the backbone of the development of rural and national economies. They comprise 43 per cent of the world's agricultural labor force, which rises to 70 per cent in some countries. In Africa, 80 per cent of agricultural production comes from small farmers, who are mostly rural women. Women comprise the largest percentage of the workforce in the agricultural sector but do not have access and control over all land and productive resources. Women play a significant and crucial role in agricultural development and allied fields. The nature and extent of women's involvement in agriculture vary greatly from region to region. But regardless of these variations, women are actively involved in various agricultural activities (Meena, Nisha (2018).

Female participation in agriculture across various Indian states from 1961-2001 shows active involvement and participation of women in the agricultural sector in almost all the states except Kerela, Punjab and West Bengal where women are actively participating in non-agricultural activities which include household industry, service sector etc. (Ghosh, Mun Mun et al. May, 2014). In developing countries like India agriculture continues to absorb and employ the female work force but fails to give them recognition of employed/hired labour. Hence, they are "invisible workers". Women manage and operate most of the household activities in the rural areas of the hills and maintain the sustainability of various sectors of the rural ecosystem (Negi, Vikram S. et al. 2010).

Sikkim is a tiny Himalayan state in India with the majority of its population depending on agriculture directly or indirectly. Women participate in agriculture and its allied activities with full vigor and zeal. Female participation dominance has been seen in most of the activities like feeding of animals, watering of animals, milking and milk disposal, which show the frequency of gender wise participation in different activities. (Dwivedy, Nidhi. 2014). Therefore, the main objective of this paper is to observe the labour force participation rate specifically women labour force participation rate in the state, edify its variation across the districts and provide a platform for future research on reasons for such variations.

\section{Data and Methodology}

The study is solely based on secondary sources. The secondary data and information were collected from the Department of Economics, Statistics, Monitoring and Evaluation, Government of Sikkim and Census of India 2011, Sikkim District Census Handbook (North, West, South and East districts). The present study analyses the labour force participation rate in agricultural and non-agricultural activities in Sikkim with special emphasis on women's work participation and its variations across the districts. The results were analyzed using descriptive statistics such as percentages and tabular representation. The statistical software namely Microsoft Excel 2010 had been used for processing, analysing and finally interpretation of the results.

\section{RESULTS AND DISCUSSION}

\section{Labour Force Participation Rate in Sikkim}

Sikkim is the $22^{\text {nd }}$ state of India came into existence with effect from $16^{\text {th }}$ May 1975. It has an area of 7,096 sq. km. and a population of 6,10,577 out of which 3,23,070 are males and 2,87,507 are females. 
The state being a part of inner ranges of the mountains of Himalaya has no open valley and no plains but carried elevations ranging from 300 to 8,585 meters above mean sea level. It is divided into four districts (i) South district, (ii) North district, (iii) East district and (iv) West district.

After the merger with India in 1975, primary attention was given to infrastructure building for accelerating non-agricultural activities. The strategy was rewarding. The non-agriculture sector of Sikkim started developing speedily. Agriculture being the mainstay, attention was also attached to this sector. Share of primary sector in State Domestic Product, however, steadily declined due to the development of non-agriculture sector. However, agriculture and allied activities continue to be the major employmentgenerating sector in Sikkim.

Table 1 below shows the total working and non-working population in Sikkim and its labour force participation rate:

Table 1: Labour Force Participation Rate in Sikkim

\begin{tabular}{lllllll}
\hline Category of Workers & $\begin{array}{l}\text { Persons } \\
\text { (In Nos.) }\end{array}$ & $\begin{array}{l}\text { Persons } \\
\text { (In \%) }\end{array}$ & $\begin{array}{l}\text { Male } \\
\text { (In Nos.) }\end{array}$ & $\begin{array}{l}\text { Male } \\
\text { (In \%) }\end{array}$ & $\begin{array}{l}\text { Female } \\
\text { (In Nos.) }\end{array}$ & $\begin{array}{l}\text { Female } \\
\text { (In \%) }\end{array}$ \\
\hline Cultivators & $1,17,401$ & 38 & 63,327 & 54 & 54,074 & 46 \\
Agricultural Labourers & 25,986 & 8 & 12,883 & 50 & 13,103 & 50 \\
Total Agricultural Workers & 143387 & 47 & 76210 & 53 & 67177 & 47 \\
$\begin{array}{l}\text { Workers in Household } \\
\text { Industry }\end{array}$ & 5,143 & 2 & 2,947 & 57 & 2,196 & 43 \\
Other Workers & $1,59,608$ & 52 & $1,15,201$ & 72 & 44,407 & 28 \\
$\begin{array}{l}\text { Total Non-Agricultural } \\
\text { Workers }\end{array}$ & 164751 & 53 & 118148 & 72 & 46603 & 28 \\
Total Workers (Main \& & $3,08,138$ & 50 & $1,94,358$ & 63 & $1,13,780$ & 37 \\
Marginal) & & & & & & \\
Main Workers & $2,30,397$ & 75 & $1,60,513$ & 70 & 69,884 & 30 \\
Marginal Workers & 77,741 & 25 & 33,845 & 44 & 43,896 & 56 \\
Non-Workers & $3,02,439$ & 50 & $1,28,712$ & 43 & $1,73,727$ & 57 \\
\hline
\end{tabular}

Source: Census of India, 2011.

Table 1 above shows that out of the total population of 6,10,577 in Sikkim, 3,23,070 are males and 2,87,507 are females. There are 3,08,138 (50 per cent) working population and 3,02,439 (50 per cent) non-working or dependent population in the state. Out of 3,08,138 working population, 1,17,401 (38 per cent) are cultivators, 25,986 (8 per cent) are agricultural labourers, 5,143 (2 per cent) are in household industry and 1,59,608 (52 per cent) are in other activities. Total agricultural workers are 1,43,387 (47 per cent) and total non-agricultural workers are 1,64,751 (53 per cent) of the total population of the state forming a total of 3,08,138 working population and 3,02,439 non-working or dependent population. Again, the total working population is divided into main and marginal workers. Out of 3,08,138 working population, 2,30,397 (75 per cent) are main workers and 77,741 (25 per cent) are marginal workers.

Both in the agricultural and non-agricultural activities, men dominated women whose participation is found to be between 50 to 72 per cent. However, while comparing the involvement of men and women as main and marginal workers, it is observed that 70 per cent of men are involved as main workers and 56 per cent of the women are actively involved as marginal workers. Finally, while comparing the male- 
female ratio as a dependent population, it is found that out of total 3,02,439 non-working or dependent population in the state, 43 per cent are males and 57 per cent are females.

\section{Labour Force Participation Rate in the Agricultural Sector in Sikkim}

Sikkim has a diverse ecological condition, which on one hand prevent the adoption of common crops and on the other hand favour cultivation of many kinds of fruits, vegetables both in and off seasons and also provide a conducive agro-climatic situation for growing commercial crops like cardamom, potato, ginger etc. Agricultural lands are situated at an elevation of 300 to 3000 metres but most of the cultivated areas lie below 1800 metres. In Sikkim most of the area of cultivable land is terraced and the land is crescent-shaped (4.5 to $7.5 \mathrm{~m}$ long and 2.5 to $3.5 \mathrm{~m}$ wide) across the steep mountain slopes (Gupta, Manas Das. (1992).

Women's labour accounts for 61 per cent of the total farm work, their participation being greater in activities like animal husbandry than in crop production (Bhati \& Singh, 1987). There is some tendency towards a sexual division of labour in agriculture. Men mostly did heavy and seasonal work such as field preparation and manuring whereas the women mostly did light and regular works. Most work in hill agriculture is light and hand operated - sowing, weeding, hoeing, harvesting, cutting of grass for fodder etc. Women work with light implements (such as sickle and hoe). Women's lowest participation is in those tasks that involve heavy implements and great physical exertion: ploughing, manuring, terracing, levelling etc. Since women contribute more in regular and non-seasonal work, in slack agricultural seasons one would rarely find a reduction in working hours for rural women in hilly areas. On an average, women work for longer hours than men due to the combination of household work and farm work.

The farm workload of hill peasant women increases with the increase in the size of farm and they participate in all farm activities except ploughing. This is opposite to the rural women in the plains whose involvement in agriculture declines with the increase in the size of the farm and who perform selected few farm activities only.

Table 2 below shows labour force participation rate in the agricultural sector in Sikkim and its variation across the districts:

Table 2: Labour Force Participation Rate in the Agricultural Sector in Sikkim

\begin{tabular}{lllllll}
\hline \multirow{2}{*}{ Work Category } & & \multicolumn{5}{c}{ Districts } \\
\cline { 3 - 6 } & & South & North & East & West & Sikkim \\
\hline \multirow{3}{*}{ Cultivators } & Persons (in Nos.) & 37,802 & 7,313 & 31,489 & 40,797 & $1,17,401$ \\
& Male (in Nos.) & 20,808 & 3,889 & 16,477 & 22,153 & 63,327 \\
& Female (in Nos.) & 16,994 & 3,424 & 15,012 & 18,644 & 54,074 \\
& Persons (in \%) & 51 & 31 & 22.5 & 58 & 38 \\
& Male (in \%) & 55 & 53 & 52 & 54 & 54 \\
\hline
\end{tabular}


Labour Force Participation Rate in Agricultural and Non-Agricultural Activities in Sikkim...

\begin{tabular}{lllllll}
\hline & Persons (in Nos.) & 4,188 & 2,262 & 11,483 & 8,053 & 25,986 \\
Agricultural & Male (in Nos.) & 2,116 & 1,308 & 5,382 & 4,077 & 12,883 \\
Labourers & Female (in Nos.) & 2,072 & 954 & 6,101 & 3,976 & 13,103 \\
& Persons (in \%) & 6 & 10 & 8 & 11 & 8 \\
& Male (in \%) & 51 & 58 & 47 & 51 & 50 \\
& Female (in \%) & 49 & 42 & 53 & 49 & 50 \\
Total Agricultural & Persons (in Nos.) & 41,990 & 9,575 & 42,972 & 48,850 & $1,43,387$ \\
Workers & Female (in Nos.) & 22,924 & 5,197 & 21,859 & 26,230 & 76,210 \\
& Persons (in \%) & 56 & 41 & 31 & 69 & 47,177 \\
& Male (in \%) & 55 & 54 & 51 & 54 & 53 \\
\hline
\end{tabular}

Census of India, 2011.

From the above table 2, it is found that 38 per cent of the working population in Sikkim, are engaged as cultivators. If we see the male female involvement, it is found that 54 per cent male and 46 per cent female are engaged as cultivators in Sikkim. There is an inter-district variation observed in this activity. West district records the highest participation in cultivation with 58 per cent people engaged in it followed by South district with 51 per cent, North district with 31 per cent and East district with 22.5 per cent people participating in it. Observing the male female participation rate in agricultural activity as cultivators, it is found that men surpass women in all the districts of the state.

With regards to agricultural labourers, it is found that men and women are involved in agricultural activities as agricultural labourers at par with each other with 50 per cent participation rate. This result provides a very important message that the women of the state are no lesser than the men in performing manual work. Hence, her contribution to the rural economy of the state cannot be overlooked. Data also reveal that the rate of participation in the agricultural sector as agricultural labourers is highest in case of West district with 11 per cent people participating in it followed by North district with 10 per cent, East district with 8 per cent and South district with 6 per cent.

Inter-district variation in male-female participation in the agricultural sector as agricultural labourer is observed. It is found that in all the districts of Sikkim male outshines the female in this activity except in East Sikkim it is seen that the female participation rate is higher than male with 53 per cent and 47 per cent respectively.

Total agricultural workers comprise the cultivators and the agricultural labourers. It is observed that 47 per cent of the working populations are engaged as agricultural workers in the state with male-female participation ratio of 53 per cent and 47 per cent respectively. There is variation across the districts in the rate of participation. West district shows the highest rate of participation with 69 per cent of its working population engaged as agricultural workers followed by South district with 56 per cent, North district with 41 per cent and East district records the lowest rate of participation with 31 per cent only. If we compare the male-female ratio of participation across the districts, men supersede women with few margins of 2 to 10 per cent. The male-female participation ratio is healthier in East district with 51 per 
cent and 49 per cent involvement respectively and shoddier in South district with 55 per cent and 45 per cent participation respectively. In North district and West district, the male-female participation ratio in agricultural activities is identical with 54 per cent and 46 per cent involvement respectively.

\section{Labour Force Participation Rate in Non-Agricultural Sector in Sikkim}

Though agriculture is the main economy of the rural people in India, to complement the family's income, they participate in different types of activities like hunting, fishing, trapping, domestication of animals, handloom and handicraft, collection of forest product etc. to supplement their subsistence. People of the village engage themselves in business and contract work and many of them are also absorbed in the government services. There is no specialization of the occupation and every household is a production unit of different items. One man can engage in different activities at the same time such as agriculture and other activities like hunting, fishing, domestication of animals, handicraft and handloom etc. representing a mixed economy (Medhi, Birichi K. and et al. 2009).

Table 4 below represent labour force participation rate in non-agricultural sector in Sikkim and its variation across the districts:

Table 4: Labour Force Participation Rate in Non-Agricultural Activity in Sikkim And Its Variation Across the Districts

\begin{tabular}{lllllll}
\hline \multirow{2}{*}{ Work Category } & & \multicolumn{5}{c}{ Districts } \\
\cline { 3 - 6 } & & South & North & East & West & Sikkim \\
\hline \multirow{3}{*}{ Household Industry } & Persons (in Nos.) & 1,004 & 332 & 2,404 & 1,403 & 5,143 \\
& Male (in Nos.) & 563 & 152 & 1,471 & 761 & 2,947 \\
& Female (in Nos.) & 441 & 180 & 933 & 642 & 2,196 \\
& Persons (in \%) & 1 & 1 & 2 & 2 & 2 \\
& Male (in \%) & 56 & 46 & 61 & 54 & 57 \\
& Female (in \%) & 44 & 54 & 39 & 46 & 43 \\
\hline \multirow{5}{*}{ Other Workers } & Persons (in Nos.) & 31,759 & 13,452 & 94,302 & 20,095 & $1,59,608$ \\
& Male (in Nos.) & 21,813 & 10,586 & 69,021 & 13,781 & $1,15,201$ \\
& Female (in Nos.) & 9,946 & 2,866 & 25,281 & 6,314 & 44,407 \\
& Persons (in \%) & 42 & 58 & 67.5 & 29 & 52 \\
& Male (in \%) & 69 & 79 & 73 & 69 & 72 \\
Total Non-Agricultural & Female (in \%) & 31 & 21 & 27 & 31 & 28 \\
\hline Workers & Persons (in Nos.) & 32,763 & 13,784 & 96,706 & 21,498 & $1,64,751$ \\
& Male (in Nos.) & 22,376 & 10,738 & 70,492 & 14,542 & $1,18,148$ \\
& Female (in Nos.) & 10,387 & 3,046 & 26,214 & 6,956 & 46,603 \\
& Persons (in \%) & 44 & 59 & 69 & 31 & 53 \\
& Male (in \%) & 68 & 78 & 73 & 68 & 72 \\
& Female (in \%) & 32 & 22 & 27 & 32 & 28 \\
\hline
\end{tabular}

Census of India, 2011.

It is equally important to understand the labour force participation rate in the non-agricultural sector, which includes work in the household industry and other activities. Table 4 above shows that 2 per cent 
of the total working population of the state is engaged in the household industry out of which 57 per cent are males and 43 per cent are females. The male-female work participation ratio is favorable for men in this activity in the state. The situation is better for East and West district with 2 per cent of its working population engaged in it than South and North districts with only 1 per cent of their working population involved in it.

Observing the male-female ratio of participation in the household industry, inter-district variation is witnessed. In all the districts males are performing better compared to females except in the North district where the women overtake the men in this activity with 54 per cent and 46 per cent involvement respectively. While comparing the performance of the women in this activity across the districts, it is found that North district is better off with 54 per cent women involved in it followed by West district with 46 per cent women involvement, South district with 44 per cent involvement and East district with only 39 per cent women involved in it. The lowest performance of the women in this activity in East district can be both positive and negative. Positive factors include better educational facility and as a result, most of the women are involved in the tertiary sector. Negative reasons include women are dependent on their men counterparts.

The type of workers that come under the category of 'Other Workers' includes all government servants, municipal employees, teachers, factory workers, plantation workers, those engaged in trade, commerce, business, transport, banking, mining, construction, political or social work, priests, entertainment artists, etc. In this category, results reveal that men in the state outperform the women with 72 per cent and 28 per cent involvement respectively. In absolute terms, it is found that 52 per cent of the working population in the state is engaged in this activity. Inter-district variation in this activity is observed in the state. East district outshines the other districts of the state in this activity with 67.5 per cent of its working population engaged in it followed by North district with 58 per cent involvement, South district with 42 per cent participation and West district with only 29 per cent of its working population engaged in it. West district records the lowest participation in this activity since the majority of its population is dependent on agriculture and its allied activities for their livelihood.

The male-female ratio of participation in this activity highlighted the existence of a patriarchal society in the state. Data show that only very few privileged women of the state have got the opportunity to be a part of this activity with their participation rate ranging between 21 per cent to 31 per cent. Therefore, the government and the NGOs should work for enhancing better educational facilities for girl child so that they become competent enough to take up jobs in this sector as well which at present is very much dominated by the males.

Involvement in household industry and "OW" (Other Workers) are categorized as non-agricultural workers. Observing the labour force participation rate in non-agricultural activity, it is found that 53 per cent of the working population in the state is engaged in it with the remaining 47 per cent engaged in agricultural activity. Data exhibit that involvement in this activity varies across the district led by East district with 69 per cent of its working population involved in it followed by North district with 59 per cent, South district with 44 per cent and West district with only 31 per cent. Considering the male-female ratio of participation, it is noticed that South and West districts are better off with male-female ratio of participation with 68 per cent and 32 per cent respectively followed by East district with 73 per cent and 27 per cent respectively and North district with 78 per cent and 22 per cent respectively. 


\section{Labour Force Participation Rate (Main \& Marginal Workers)}

In terms of participation in the work force in Sikkim, there are considerable variations. The percentage of main workers to the total population is 46.6 in Sikkim and the percentage of marginal workers in the state is 1.7. The remaining 51.7 per cent of the total population in the state has been treated as non-workers under the concept of workers and non-workers adopted in 1981 census (Gupta, Manas Das. 1992).

Table 5 below shows the labour force participation rate in Sikkim (main \& marginal workers) and its variations across the districts:

Table 5: Labour Force Participation Rate in Sikkim (Main \& Marginal Workers): Variation Across the Districts

\begin{tabular}{|c|c|c|c|c|c|c|}
\hline \multirow{2}{*}{ Work Category } & & \multicolumn{5}{|c|}{ Districts } \\
\hline & & South & North & East & West & Sikkim \\
\hline \multirow{6}{*}{ Main Workers } & Persons (in Nos.) & 50,898 & 17,216 & $1,11,058$ & 51,225 & $2,30,397$ \\
\hline & Male (in Nos.) & 35,271 & 12,677 & 79,311 & 33,254 & $1,60,513$ \\
\hline & Female (in Nos.) & 15,627 & 4,539 & 31,747 & 17,971 & 69,884 \\
\hline & Persons (in \%) & 68 & 74 & 80 & 73 & 75 \\
\hline & Male (in \%) & 69 & 74 & 71 & 65 & 70 \\
\hline & Female (in \%) & 31 & 26 & 29 & 35 & 30 \\
\hline \multirow{6}{*}{ Marginal Workers } & Persons (in Nos.) & 23,855 & 6,143 & 28,620 & 19,123 & 77,741 \\
\hline & Male (in Nos.) & 10,029 & 3,258 & 13,040 & 7,518 & 33,845 \\
\hline & Female (in Nos.) & 13,826 & 2,885 & 15,580 & 11,605 & 43,896 \\
\hline & Persons (in \%) & 32 & 26 & 20 & 27 & 25 \\
\hline & Male (in \%) & 42 & 53 & 46 & 39 & 44 \\
\hline & Female (in \%) & 58 & 47 & 54 & 61 & 56 \\
\hline \multirow{6}{*}{$\begin{array}{l}\text { Total Workers } \\
\text { (Main + Marginal) }\end{array}$} & Persons (in Nos.) & 74,753 & 23,359 & $1,39,678$ & 70,348 & $3.08,138$ \\
\hline & Male (in Nos.) & 45,300 & 15,935 & 92,351 & 40,772 & $1,94,358$ \\
\hline & Female (in Nos.) & 29,453 & 7,424 & 47,327 & 29,576 & $1,13,780$ \\
\hline & Persons (in \%) & 51 & 53 & 49 & 52 & 50 \\
\hline & Male (in \%) & 61 & 68 & 66 & 58 & 63 \\
\hline & Female (in \%) & 39 & 32 & 34 & 42 & 37 \\
\hline \multirow{6}{*}{ Non-Workers } & Persons (in Nos.) & 72,097 & 20,350 & $1,43,905$ & 66,087 & $3,02,439$ \\
\hline & Male (in Nos.) & 31,370 & 8,795 & 59,081 & 29,466 & $1,28,712$ \\
\hline & Female (in Nos.) & 40,727 & 11,555 & 84,824 & 36,621 & $1,73,727$ \\
\hline & Persons (in \%) & 49 & 47 & 51 & 48 & 50 \\
\hline & Male (in \%) & 44 & 43 & 41 & 45 & 43 \\
\hline & Female (in \%) & 56 & 57 & 59 & 55 & 57 \\
\hline
\end{tabular}

Census of India, 2011.

Table 5 above shows the number of main and marginal workers and its percentage share out of the total working population in the state. Data reveal that 75 per cent of the working populations in the state are main workers and 25 per cent are marginal workers, certainly an optimistic indication that the majority 
of our population in the state is getting more days of employment. Looking at the male-female ratio of participation, it is found that males surpass women in the main workers category with 70 per cent and 30 per cent involvement respectively whereas women overtake the men in the marginal workers category with 56 per cent and 44 per cent participation respectively. Variations across the districts is observed in these activities with East district leading in main workers category with 80 per cent of its working population engaged in it followed by North district with 74 per cent contribution, West district with 73 per cent association and South district with 68 per cent involvement. Contradictory will be the situation in case of marginal workers.

Viewing the labour force participation rate in total workers category combining both the main and the marginal workers, it is found that 50 per cent of the total population of the state is engaged in it. In other words, 50 per cent are working population and the outstanding 50 per cent are the dependent or the nonworking population. This figure is a great concern to all the stakeholders of the state especially the policy makers. Steps need to be taken to produce more employment opportunities in the state and involve more people in work to enhance the state's economy. The male-female participation rate also differs in the state where it is perceived that the males are in a better position than the females with 63 per cent and 37 per cent involvement respectively.

Work participation rate varies across the districts with maximum participation observed in North district with 53 per cent of its population engaged in it followed by West district with 52 per cent involvement, South district with 51 per cent partaking and East district with 49 per cent contribution. This data unveils the fact that 53 per cent of the total population in North district is working population followed by West district with 52 per cent, South district with 51 per cent, whose figure is a bit higher than the state's average and for East district it is 49 per cent which is less than the state's average. Both at the district and the state level, the situation is intimidating. With such a huge burden of non-working or dependent population, development of the state would remain a mere nightmare.

Considering the male female participation ratio, again it fluctuates across the districts. It is healthier in case of West district with male-female involvement of 58 per cent and 42 per cent respectively followed by South district with 61 per cent and 39 per cent respectively, East district with 66 per cent and 34 per cent respectively and North district with 68 per cent and 32 per cent respectively.

Finally, it is observed that across the districts and the state, the non-working population is higher in case of females than the males but this figure cannot underestimate the contribution of the womenfolk on the ground that her participation in the rural economy of the state ranges between 32 per cent involvement in North district to 42 per cent involvement in West district with 37 per cent participation at the state level on an average.

\section{CONCLUSION}

Sikkim the tiny Himalayan state of India has a total population of 6,10,577 with 3,23,070 males and $2,87,507$ females. The share of the total working and non-working population in the state was 50 per cent each. Out of the total population 47 per cent were agricultural workers and 53 per cent were nonagricultural workers; 75 per cent were main workers and 25 per cent were marginal workers. However, while comparing the involvement of men and women as main and marginal workers, it was observed that 70 per cent of men were involved as main workers and 56 per cent of the women were actively involved as marginal workers. Both in agricultural and non-agricultural activities, men dominated 
women. In activity such as agricultural labourers, women performed at par with men, which provided a very important message that the women of the state were no lesser than the men in performing manual work. If given an opportunity, hill women can perform better than their male counterparts. Therefore, Government policies regarding agricultural growth should involve more women and the strategy must be women-centric.

Inter-district variations were observed in agricultural and non-agricultural activities. West district recorded the highest participation in cultivation with 58 per cent people engaged in it while East district recorded the lowest participation rate of 22.5 per cent only. The result also revealed that the rate of participation in the agricultural sector as agricultural labourers was highest in case of West district with 11 per cent people participating in it while only 6 per cent participation in South district. In household industry, the performance of East district was highest with 69 per cent of its population engaged in it while West district recorded the lowest participation rate with only 31 per cent involvement. In other non-agricultural activities especially in the service sector, East district outshined the other districts of the state with 67.5 per cent of its working population engaged in it followed by North district with 58 per cent involvement, South district with 42 per cent participation and West district with only 29 per cent of its working population engaged in it. Therefore, data revealed that East district was performing well in the non-agricultural sector and the West district in the agricultural sector, which reflects regional imbalance in the economic sense. The reasons for such variations are better educational services in East district, which provide platform to its population to excel in non-agricultural sector whereas lack of such amenity has acted as a hindrance for the people of West district to perform better in the non-agricultural sector leading for their excessive dependence on the agricultural sector. Henceforth, the Government should provide agricultural and nonagricultural facilities accordingly across the districts and gender and provide appropriate awareness and training programmes to all the stakeholders so that every district shines in every activity equivalently.

The male-female ratio of participation in the non-agricultural sector also highlights the existence of a patriarchal society in the state. Data showed that only very few privileged women of the state have got the opportunity to be a part of this activity with their participation rate ranging between 21 per cent to 31 per cent. Therefore, the government and the NGO's should work for enhancing better educational facilities for girl child so that they become competent enough to take up jobs in this sector as well which at present is very much dominated by the males.

Finally, it was observed that across the districts and the state, the non-working population was higher in case of females than the males. This figure cannot undervalue her contribution as her participation in the rural economy of the state ranges between 32 per cent in North district to 42 per cent in West district with 37 per cent at the state level on an average. Therefore, her contribution to the rural economy of the state cannot be ignored. The government should help the womenfolk through its policies and amendments in laws favoring her, conducting awareness and training programmes for her making her efficient enough to face the challenges, which prevented her from being at parity with her male counterpart. In other words, the Government of Sikkim should give strength and confidence to the women to realize their potential and capabilities in agricultural as well as non- agricultural spheres of activities by providing equal distribution of power irrespective of gender. This will surely help in attaining gender equality on one hand and enrich the state both socially and economically on the other hand. 


\section{Important Concepts}

Work: Work is defined as participation in any economically productive activity with or without compensation, wages or profit. Such participation may be physical and/or mental in nature. Work involves not only actual work but also includes effective supervision and direction of work. It even includes part time help or unpaid work on farm, family enterprise or in any other economic activity. All persons engaged in 'work' as defined above are workers. Persons who are engaged in cultivation or milk production even solely for domestic consumption are also treated as workers. Reference period for determining a person as worker and non-worker is one year preceding the date of enumeration.

Main worker: A person who has worked for major part of the reference period (i.e. six months or more during the last one year preceding the date of enumeration) in any economically productive activity is termed as 'Main worker'.

Marginal worker: A person who worked for less than six months of the reference period (i.e. in the last one year preceding the date of enumeration) in any economic activity is termed as 'Marginal worker'.

Non worker: A person who has not worked at all in any economically productive activity during the reference period (i.e. last one year preceding the date of enumeration ) is termed as 'Non worker'.

Cultivator: For purposes of the Census a person is classified as cultivator if he or she is engaged in cultivation on land owned or held from government or held from private persons or institutions for payment in money, kind or share. Cultivation includes effective supervision or direction in cultivation. A person who has given out her/his land to another person or persons or institution(s) for cultivation for money, kind or share of crop and who does not even supervise or direct cultivation in exchange of land, is not treated as cultivator. Similarly, a person working on another person's land for wages in cash or kind or a combination of both (agricultural labourer) is not treated as cultivator. Cultivation involves ploughing, sowing, harvesting and production of cereals and millet crops such as wheat, paddy, jowar, bajra, ragi, etc. and other crops such as sugarcane, tobacco, ground-nuts, tapioca, etc., and pulses, raw jute and kindred fiber crop, cotton, cinchona and other medicinal plants, fruit growing, vegetable growing or keeping orchards or groves, etc. Cultivation does not include the following plantation crops - tea, coffee, rubber, coconut and betel-nuts (areca).

Agricultural labourer: A person who works on another person's land for wages in money or kind or share is regarded as an agricultural labourer. She/he has no risk in the cultivation, but merely works on another person's land for wages. An agricultural labourer has no right of lease or contract on land on which she/he works. For Certain reasons, the growing of certain crops viz. tea, coffee, rubber, pepper, coconut and betel nuts etc. is not considered as agriculture. Hence, if a person is engaged in the growing of such crops he or she is not considered as cultivator or agricultural labourer.

Workers in Household Industry: Household Industry is defined as an industry conducted by the head of the household himself/herself and or by the members of the household at home or within the village in rural areas and only within the precincts of the house where the household lives in urban areas. The larger proportion of workers in the household industry should consist of members of the household including the head. The industry should not be run on the scale of a registered factory, which would qualify or has to be registered under the Indian Factories Act. There may be an industry which is being run by a large joint family of more than 10 persons and where power is used or more than 20 persons where power is not used. In such cases, though only family members are involved, this will not be treated as 'Household 
Industry'. Thus, the meaning of the term 'run on the scale of registered factory' refers to such cases even if these are not registered as such. The main criterion of a Household Industry is the participation of one or more members of a household. This criterion will apply in urban areas too. Even if the industry is not actually located at home in rural areas there is a greater possibility of the members of the household participating even if it is located anywhere within the village limits. In the urban areas where organised industry takes greater prominence, the Household Industry should be confined to the precincts of the house where the participants live. In urban areas, even if the members of the household run an industry by themselves but at a place away from the precincts of their home, it will not be considered as a Household Industry. It should be located within the precincts of the house where the members live in the case of urban areas. A Household Industry should relate to production, processing, servicing, repairing or making and selling of goods. However, a household can be engaged in certain other activities collectively but these may not qualify for being considered as Household Industry.

Other worker: A person who has been engaged in some economic activity during the reference period but not as a cultivator or agricultural labourer or in Household Industry is termed as a 'Other Worker'. The type of workers that come under this category of ' $\mathrm{OW}$ ' include all government servants, municipal employees, teachers, factory workers, plantation workers, those engaged in trade, commerce, business, transport, banking, mining, construction, political or social work, priests, entertainment artists, etc. In effect, all those workers other than cultivators or agricultural labourers or household industry workers are 'Other Workers'.

Work participation rate: Percentage of workers (main + marginal) to total population.

\section{REFERENCES}

1. Doss, C. et al. 2011. The Role of Women in Agriculture. ESA Working Paper No. 11-02, March, 2011. Agricultural Development Economics Division. The Food and Agriculture Organization of the United Nations.

2. Meena, N. 2018. Role of women in agriculture and its allied fields. International Youth Journal. 28 ${ }^{\text {th }}$ June 2018 at 21:51.

3. Ghosh, Mun Mun et al. 2014. Analysis of Women Participation in Indian Agriculture. Journal of Humanities and Social Science (IOSR-JHSS), 5(19): 01-06.

4. Negi, Vikram S. et al. 2010. Work Participation and Role of Gender in Village Ecosystem, Central Himalaya, India. An International Journal of Science \& Technology. ISSN: 0975-7112.

5. Dwivedy, N. 2014. Role of Female Labour in Farming Sector: A Study of State of Sikkim. Doctor of Philosophy, Department of Management Studies, Sikkim Manipal Institute of Technology.

6. Census of India, 2011. Sikkim, District Census Handbook, Series-12, Part XII-A. Directorate of Census Operations, Sikkim.

7. Census of India, 2011. Sikkim, District Census Handbook, Series-12, Part XII-B. Directorate of Census Operations, Sikkim.

8. Rural Management and Development Department, Government of Sikkim. 
9. Urban Development and Housing Department, Government of Sikkim.

10. Sikkim Prajantantrik Morcha, Nagar Palika/Nagar Parishad/Nagar Panchayat;2010-2014. Zilla Adhyaksha/ Zilla Panchayat/ Panchayats; 1997, 2002, 2007, 2012. Kendriya Karyalaya, SDF Bhawan, Indira By Pass, Gangtok. Silver Jubilee Celebration Committee. 2017.

11. Sikkim Human Development Report 2014.

12. State Industrial Profile of Sikkim, 2014-2015. Ministry of MSME (Micro, Small \& Medium Enterprises), Government of India.

13. Gupta and Das. M.1992. Sikkim: Problems and Prospects of Development, Indus Publishing Company, New Delhi.

14. Medhi and Birichi K. and et al. 2009. Tribes of North-East India, Issues and Challenges. Omsons Publications, New Delhi, First Published 2009.

15. Bhati, J.P. and Singh, D.V. 1987. Women's Contribution to Agricultural Economy in Hill Regions of North-West India. Economic and Political Weekly, 22(17): WS7-WS11.

16. https://www.shareyouressays.com/essays/essay-on-rural-urban-composition-of-population-in-india-857words/120698 accessed on $19^{\text {th }}$ December 2020 at 8:33 am.

17. https://southsikkim.nic.in/about-district/district-profile/ accessed on $24^{\text {th }}$ Dec. 2020 at 4:20 pm.

18. https://northsikkim.nic.in/district-profile/ accessed on $24^{\text {th }}$ Dec. 2020 at 4:24 pm.

19. https://eastsikkim.nic.in/about-district/ accessed on $24^{\text {th }}$ Dec. 2020 at $4: 28 \mathrm{pm}$

20. https://westsikkim.nic.in/brief-resume/ accessed on $24^{\text {th }}$ Dec. 2020 at 4:29 pm 
